\title{
Temporal and spatial variability in settlement and recruitment of echinoderms in kelp beds and barrens in Nova Scotia
}

\author{
Toby Balch*', Robert E. Scheibling \\ Department of Biology, Dalhousie University, Halifax, Nova Scotia B3H 4J1, Canada
}

\begin{abstract}
Settlement and recruitment of echinoderms were measured in 2 adjacent habitats: a kelp bed (Laminaria longicruris) and an echinoid (Strongylocentrotus droebachiensis)-dominated barren ground at each of 2 sites in the rocky subtidal zone (5 to $10 \mathrm{~m}$ depth) off Nova Scotia. Settlement was measured using artificial collectors made of $0.05 \mathrm{~m}^{2}$ panels of plastic turf that were deployed $0.2 \mathrm{~m}$ (low) and $2.3 \mathrm{~m}$ (high) above the bottom in each habitat, and sampled bi-weekly from June to November 1992 to 1994. Distinct settlement pulses of ophiuroids (Ophiopholis aculeata and Ophiura spp.), asteroids (Asterias spp.) and an echinoid (S. droebachiensis) occurred between July and September of each year at both sites. Timing of settlement differed consistently among species in relation to differences in timing of spawning and larval development. The magnitude of each pulse varied between years and species, and the year of maximum settlement differed between species, suggesting that species-specific processes regulate settlement rather than general environmental conditions. Settlement of all species was greater at the more protected site, but between-habitat patterns were not consistent among species. Asteroids settled in greater numbers in and above kelp beds, whereas ophiuroids showed a trend toward greater settlement in the barrens. The echinoid $S$. droebachiensis also tended to settle more in barrens, although the difference was not statistically significant. This suggests that kelp beds do not exhibit a consistent or strong effect on settlement. Sampling settlement concurrently at different frequencies (3 to $48 \mathrm{~d}$ ) gave different estimates of settlement, indicating a need for assessment of sampling artifacts (e.g. changes in collector quality, post-settlement mortality or migration) that can occur over longer deployment intervals. For most species sampled, settlement predicted recruit density in natural populations the following year. However, the strength of the relationship varied between species, probably because of differing postsettlement processes.
\end{abstract}

KEY WORDS: Settlement · Recruitment $\cdot$ Kelp beds $\cdot$ Barrens $\cdot$ Artificial collectors $\cdot$ Echinoidea Asteroidea $\cdot$ Ophiuroidea Resale or republication not permitted without written consent of the publisher

\section{INTRODUCTION}

The importance of larval supply, settlement and recruitment as determinants of population structure and dynamics of marine invertebrates with planktonic larvae has been the subject of considerable research over the past 2 decades (reviewed by Underwood \& Fairweather 1989, Ólafsson et al. 1994, Booth \& Bros-

${ }^{*}$ E-mail: tobybalch@yahoo.com nan 1995, Caley et al. 1996). In particular, many studies have shown that temporal and spatial variability in settlement are important in regulating recruitment, and can occur at temporal scales that range from days to years, or even decades, and spatial scales of metres to kilometres (reviewed by Ebert 1983, Butman 1987, Balch \& Scheibling in press).

Most studies have inferred patterns of settlement from those of recruitment, which may confound settlement with post-settlement mortality or migration (re- 
viewed by Connell 1985, Gosselin \& Qian 1997, Hunt \& Scheibling 1997). For example, variation in sampling method and frequency have been shown to significantly affect measures of barnacle recruitment in relation to differences in post-settlement mortality (Minchinton \& Scheibling 1993). The increasing use of artificial-settlement collectors enables direct quantification of settlement by sampling at frequent intervals, and thereby minimizing the effects of predation and migration (e.g., Harrold et al. 1991, Keesing et al. 1993, Ebert et al. 1994, Harris et al. 1994). Sampling-collector arrays facilitates replication in space and time and separation of settlement from post-settlement processes (Harrold et al. 1991). However, different collector types should be calibrated for comparisons across studies (Balch et al. 1998) and related to recruitment in natural habitats to determine links between larval supply and population structure and dynamics.

Differences in population densities of echinoids have been attributed to lower rates of recruitment in kelp beds/forests than in echinoid-dominated barrens in the northeast Pacific (Tegner \& Dayton 1981), and northwest (Scheibling 1986) and northeast (Leinaas \& Christie 1996) Atlantic. However, studies comparing settlement rates of echinoids between these 2 habitats have yielded inconsistent results, and the relative roles of settlement versus post-settlement processes in determining recruitment patterns remain poorly understood (reviewed by Balch \& Scheibling in press). Along the Atlantic coast of Nova Scotia, large tracts of the rocky subtidal zone fluctuate between kelp beds and barrens on a decadal time scale (Miller 1985, Scheibling 1986, Scheibling et al. 1999). During the early 1990s, this region was in transition from kelp beds to barrens because of destructive grazing of kelp by the echinoid Strongylocentrotus droebachiensis (Scheibling et al. 1999). This provided a rare opportunity to compare settlement and recruitment between these adjacent habitat types without the potential confounding effects of between-site variability.

To determine whether the factors that regulate settlement and recruitment are habitat or species-specific, we sampled several species of echinoderms with dispersing planktotrophic larvae that are typical of many marine benthic invertebrates (Strathmann 1987). Most of the species occur in high densities at our sites (Dempsey 1996, R.E.S. unpubl. data) and are dominant components of the rocky subtidal ecosystem along the Atlantic coast of Nova Scotia. To determine the importance of scale in regulating settlement and recruitment of these species, we measured settlement in artificial collectors and recruitment to natural substrata at temporal scales of days to years, and spatial scales of $10 \mathrm{~s}$ of metres between and within habitats (kelp beds and barrens), and kilometres between sites. We relate settlement to recruitment and show that both general patterns and species-specific variability are important in establishing and maintaining these populations in the rocky subtidal ecosystem.

\section{MATERIALS AND METHODS}

Sites. Patterns of echinoderm settlement and recruitment were measured at 2 sites selected for their differing hydrodynamic regimes: Mill Cove $\left(44^{\circ} 34.9^{\prime} \mathrm{N}\right.$, $64^{\circ} 3.2^{\prime} \mathrm{W}$ ) in St. Margaret's Bay, a large semi-protected embayment, and Little Duck Island $\left(44^{\circ} 22.0^{\prime} \mathrm{N}\right.$, $64^{\circ} 11.0^{\prime} \mathrm{W}$ ), an exposed island at the mouth of Mahone Bay (see map in Balch et al. 1999). The substratum at Mill Cove consists of granitic boulders and bedrock pavement at 6 to $10 \mathrm{~m}$ depth (below mean sea level). At Little Duck Island, broad ridges of grooved basalt form the seabed at 5 to $7 \mathrm{~m}$ depth. Both sites encompassed an echinoid (Strongylocentrotus droebachiensis)-dominated barrens and a kelp bed (Laminaria longicruris), with high densities of $S$. droebachiensis (up to $400 \mathrm{~m}^{-2}$ ) aggregated at the interface between habitats and destructively grazing the kelp. This echinoid front advanced shoreward 10 to $15 \mathrm{~m}$ during the study period (Scheibling et al. 1999), leaving new barrens, dominated by encrusting coralline algae, in its wake. Kelp morphology differed between sites in accordance with the differing flow regimes (Gerard \& Mann 1979): L. longicruris had longer stipes and longer and broader fronds at Mill Cove than at Little Duck Island. This resulted in a higher canopy at Mill Cove, although the kelp at this more protected site usually lay along the substratum whereas those at Little Duck Island often were suspended by wave surge. The understory in the kelp bed was composed of turfs of articulated coralline algae Corallina officinalis and various other red algae (e.g., Ceramium rubrum, Chondrus crispus, Palmaria palmata). For a further description of the sites and destructive grazing by the echinoid front see Scheibling et al. (1999).

Settlement sampling. Settlement collectors were constructed from $20 \times 14 \mathrm{~cm}$ diameter PVC pipes mounted on a plastic vane and attached to a rope by swivels to allow orientation into the current. Each pipe was lined with $0.05 \mathrm{~m}^{2}$ pieces of polyethylene plastic turf (PNS-3, Monsanto Canada Inc.), which served as a settlement substrate. The turf liners were protected from macro-predators by plastic light-diffuser grating (1 $\mathrm{cm}$ aperture). The collector design was modified after Harrold et al. (1991) to accommodate the plastic turf, which Harris et al. (1994) showed to be an effective settlement surface for Strongylocentrotus droebachiensis. For further description of the collectors see Balch et al. (1998). 
Within each habitat (barrens and kelp bed), 4 collector stations were spaced at $10 \mathrm{~m}$ intervals along the same depth contour, and $\sim 15 \mathrm{~m}$ from the interface between habitats, giving 2 parallel series of stations $\sim 30 \mathrm{~m}$ apart. At each station, paired collectors were suspended at 2 heights off the bottom, $0.2 \mathrm{~m}$ (low) and $2.3 \mathrm{~m}$ (high), giving 4 sampling strata (kelp high, kelp low, barrens high, barrens low). Low collectors in kelp beds were within the kelp canopy and high collectors were $>1 \mathrm{~m}$ above the canopy at each site. Because high and low collectors in both habitats sampled different regions of the water column with different flow rates and temperatures (Balch et al. 1999), we consider them to be independent for statistical analyses. At the beginning of each year, the position of stations was adjusted to maintain a similar distance from the interface, which shifted from year to year because of the advancing echinoid front. We used a systematic design to limit potential confounding effects of location (e.g., depth, distance from interface), given logistical constraints on replication.

Throughout the study, settlement was monitored in 1 of the paired collectors at each stratum at all stations at bi-weekly intervals from 11 June to 20 November 1992, 26 May to 11 November 1993, and 9 June to 16 October 1994. Sampling was staggered between sites by $\sim 1$ wk for logistical reasons. Initially, settlers from 2 of the 4 stations (20 $\mathrm{m}$ apart) within each habitat were counted to record temporal patterns in settlement. The remaining 2 stations also were counted for the $2 \mathrm{wk}$ period of highest settlement for each species, site and year. From 11 to 24 July 1992 at Mill Cove only, we concurrently sampled both of the paired collectors at all stations to examine spatial variability within habitats in a nested ANOVA.

We define settlement operationally as the number of larvae of a species/genus that attach to the turf during a 2 wk period. We assume that the short sampling period and the design of our collectors minimise postsettlement mortality and emigration. To determine the effect of sampling frequency on our estimate of settlement, we sampled the second of the paired collectors at all stations at Mill Cove at intervals less than or greater than $2 \mathrm{wk}$. Thus, settlement at successive $3 \mathrm{~d}$ intervals from 21 July to 5 August 1993 was summed and compared to measures from concurrent bi-weekly samples for each combination of collector height and habitat. Similarly, settlement summed over 3 successive 16 d intervals from 9 June to 27 July 1994 was compared to concurrent $48 \mathrm{~d}$ samples. The amount of algal/detrital fouling on collectors and the abundance of herbivorous gammarid amphipods (which could reduce fouling) also were measured in the $48 \mathrm{~d}$ samples to examine their potential effects on settlement at different collector heights. As an index of fouling, we measured the thickness (in $\mathrm{mm}$ ) of layers of sediment and flocculent material in standardised sample bottles.

Collectors were sampled by divers, who removed the plastic turf, immediately placed it in a sealed plastic bag, and replaced it with a new piece of turf and cleaned plastic grating. Replacement turf was presoaked in tanks of flowing $50 \mu \mathrm{m}$ filtered seawater for $\sim 1$ wk prior to deployment to allow for growth of a microbial film (Pearce \& Scheibling 1991). Samples were returned to the laboratory for processing within $6 \mathrm{~h}$ of collection. The turf was soaked in $50 \% \mathrm{EtOH}$ or 7 to $8 \% \mathrm{MgCl}_{2}$ for 10 to $20 \mathrm{~min}$ and then gently agitated and rinsed with filtered seawater to remove settlers. The rinse water, together with the water from the sample bag, was filtered through a $150 \mu \mathrm{m}$ Nitex $^{\circledR}$ mesh screen (small enough to retain echinoderm settlers). The retained contents of the sample were stored in $70 \% \mathrm{EtOH}$ for subsequent identification and enumeration of settlers using a Bogorov tray under a dissecting microscope.

Settlers of ophiuroids (Ophiopholis aculeata and Ophiura spp.), asteroids (Asterias spp.) and an echinoid (Strongylocentrotus droebachiensis) were identified from descriptions in the literature (Agassiz et al. 1883, Russell-Hunter 1979, Pearse et al. 1987, Todd \& Laverack 1991, Medeiros-Bergen et al. 1998). Adults of Ophiura robusta occur in low numbers at both sites, although some settlers may have been O. sarsi, which is common in deeper waters (Packer et al. 1994). A. vulgaris and $A$. forbesi occur at both sites, with $A$. vulgaris being the more common species. Because we were unable to identify to species the settlers of Ophiura and Asterias, we refer to them by genus.

Recruitment sampling. We define recruitment operationally as juveniles that survive to be counted $\sim 1 \mathrm{yr}$ after settlement. The size of 1 yr old echinoderm recruits was determined from published growth rates and inspection of size-frequency distributions based on field samples (see below). We designated echinoids $\leq 8 \mathrm{~mm}$ (horizontal test diameter) as recruits of Strongylocentrotus droebachiensis based on growth rates for this species of 6 to $8 \mathrm{~mm}$ in the first year measured under laboratory and field conditions in Nova Scotia (Raymond \& Scheibling 1987). We designated asteroids $\leq 10 \mathrm{~mm}$ (radius) as recruits of Asterias spp., which is consistent with early growth rates of $A$. vulgaris measured in the field in temperate waters (Smith 1940, Barker \& Nichols 1983, Nichols \& Barker 1984, Himmelman \& Dutil 1991). We combined juvenile A. vulgaris and $A$. forbesi with small individuals that could only be identified to genus. Identifying ophiuroid recruits was complicated by a lack of juvenile growth data for Ophiopholis aculeata and Ophiura robusta, and the absence of distinct cohorts in our samples. Packer et al. (1994) report growth rates of Ophiura 
sarsi of 2 to $4 \mathrm{~mm}$ (disc diameter) in the first year at $150 \mathrm{~m}$ depth in the Gulf of Maine. Because modal size of $O$. sarsi from this population was $\sim 7$ times larger than that of $O$. robusta and $\sim 3$ times larger than that of $O$. aculeata at our sites, we designated individuals $\leq 2 \mathrm{~mm}$ as recruits of $O$. robusta and individuals $\leq 4 \mathrm{~mm}$ as recruits of $O$. aculeata.

To compare the density of echinoderm recruits between years, sites and habitats, we collected and measured all individuals of each species from 6 to 10 quadrats of $1 \mathrm{~m}^{2}$ randomly positioned along a belt transect of $4 \times 50 \mathrm{~m}$ (Strongylocentrotus droebachiensis in both habitats at Mill Cove in 1995, and in the barrens at Little Duck Island in 1993, were measured in only 4 quadrats). Each transect extended alongshore in each habitat at each site, parallel to and $\sim 5 \mathrm{~m}$ (in the direction of the echinoid front) from the line of collector stations. Quadrats were sampled by divers between 30 August and 21 October 1993, 14 July and 2 September 1994, and 13 July and 31 August 1995. The location of the transect was staggered by 2 to $3 \mathrm{~m}$ each year to avoid overlap with previous transects and to maintain a similar position relative to the collector stations and the advancing echinoid front.

Within each $1 \mathrm{~m}^{2}$ quadrat, a $0.1 \mathrm{~m}^{2}$ inset quadrat was sampled using a suction device to sample individuals as small as $1 \mathrm{~mm}$. The remainder of the quadrat $\left(0.9 \mathrm{~m}^{2}\right)$ was carefully searched by divers, who removed and manually sorted through algal turfs and broke up coralline crusts to locate small and cryptic individuals. For each quadrat, echinoderms (and other invertebrates) were placed in sealed plastic bags. Samples were sorted in the laboratory, where echinoderms were identified and measured with vernier calipers (0.1 mm precision). Measures from the 0.9 and $0.1 \mathrm{~m}^{2}$ quadrats were combined to obtain the density of recruits per $1 \mathrm{~m}^{2}$. The comparability of the 2 methods of sampling recruits was assessed by calculating the ratio of the number of recruits collected in the $0.9 \mathrm{~m}^{2}$ portion to those collected in the $0.1 \mathrm{~m}^{2}$ portion, pooled over all quadrats within each transect. In most cases, the ratio approximated 9, indicating that differences in sam-

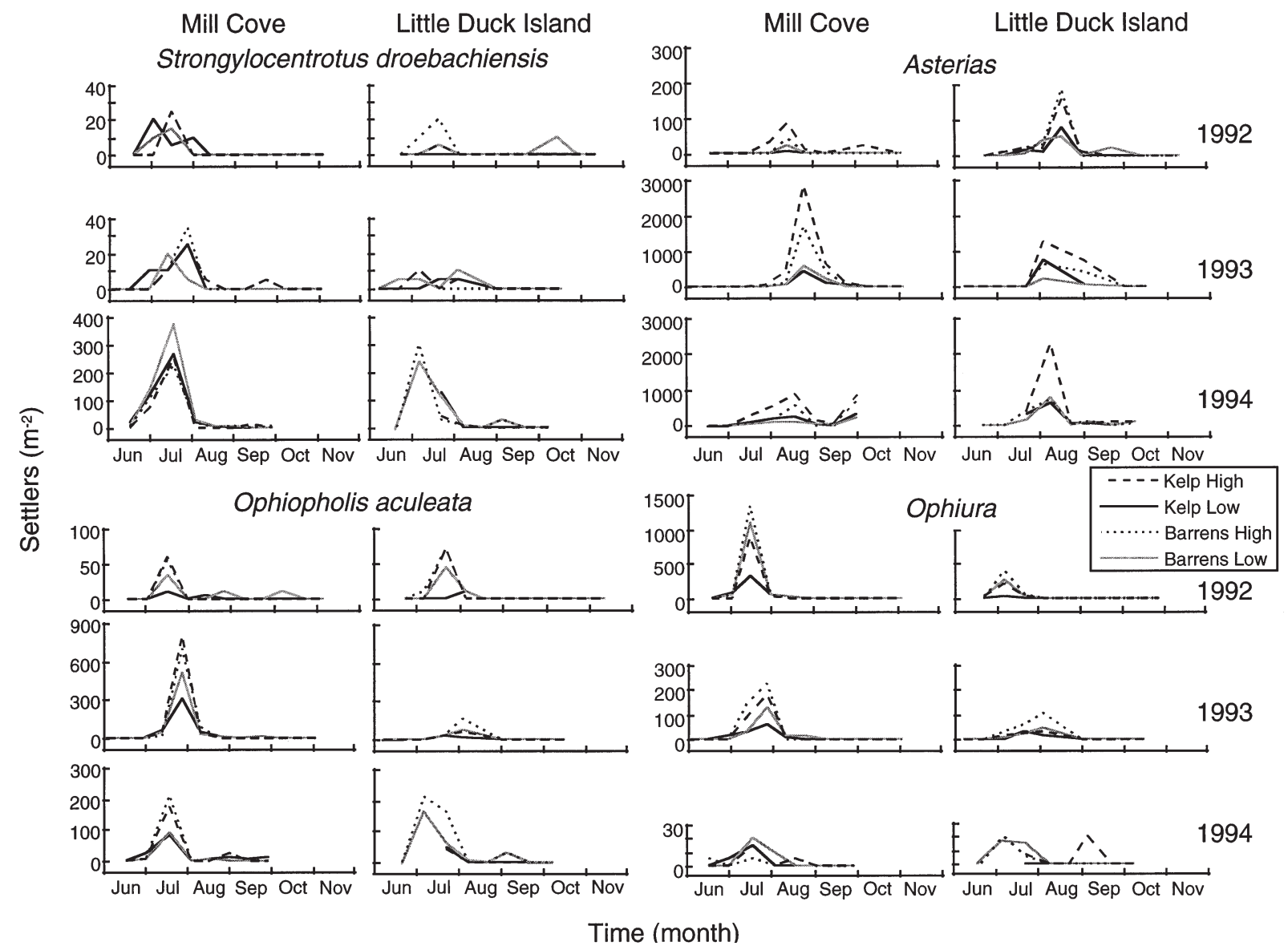

Fig. 1. Strongylocentrotus droebachiensis, Asterias spp., Ophiopholis aculeata and Ophiura spp. Mean density of settlers in collectors at 2.3 and $0.2 \mathrm{~m}$ off bottom (high and low) in 2 habitats (kelp bed and barrens) from June to November 1992 to 1994 at Mill Cove and Little Duck Island. Data are plotted at midpoint of each bi-weekly sampling interval (n=2 to 4$)$ 
pling methodology or sampling scale had little effect on our estimates of recruitment. Exceptions to this were samples in the kelp bed at Little Duck Island of Strongylocentrotus droebachiensis in 1995, and Asterias spp. in 1993 and 1994, where ratios ranged from 1.4 to 3.2 , indicating that recruitment may have been slightly underestimated in the $0.9 \mathrm{~m}^{2}$ quadrats. Individuals of each species/genus were pooled over all quadrats in a habitat to record size distributions.

Statistical analyses. Effects on settlement and recruitment of site, habitat, collector height (for settlement) and year were examined using factorial ANOVA. Analysis of settlement is based on 4 replicate collectors sampled over the $2 \mathrm{wk}$ period of highest settlement. Effects on settlement of sampling frequency, habitat and height also are examined by factorial ANOVA based on 4 replicate collectors. All analyses are based on counts of settlers per collector (i.e., $0.05 \mathrm{~m}^{2}$ of turf) but converted to settlers per $\mathrm{m}^{2}$ for comparability with recruitment measurements. Periods of low settlement (mean density $\leq 2$ settlers per collector) within a site were excluded from statistical analysis. Analysis of recruitment data is based on 6 to 10 (occasionally 4) replicate quadrats sampled in each site, habitat and year. All factors are considered fixed, including site because the sites were selected to represent 2 different hydrodynamic environments. Cochran's test was conducted prior to ANOVA to test the assumption of homogeneity of variance $(\alpha=0.05)$. Where necessary, raw data were $\log$-transformed $(\ln [x+1])$ to satisfy this assumption and to accommodate zero values. Post-hoc comparisons were made using Tukey's HSD test $(\alpha=0.05)$.

\section{RESULTS}

\section{Temporal and spatial patterns of settlement}

Settlement of echinoderms in the kelp bed and barrens mainly occurred over $\sim 2$ wk periods between July and September of each year (Fig. 1). The magnitude and timing of each settlement peak varied between species and years, and the year of maximum settlement differed between species. Most settlement occurred during the summer months when sea temperature was at or near the yearly maximum.

Settlement of the echinoid Strongylocentrotus droebachiensis was consistently low at both sites in 1992 and 1993, but increased by an order of magnitude in 1994 (Fig. 2). Analysis of the 1994 settlement peak indicated no significant difference between habitats $\left(F_{1,12}=0.962, \mathrm{p}=0.346\right)$ or collector heights $\left(F_{1,12}=\right.$ $3.200, \mathrm{p}=0.099)$ at Mill Cove. There also was no significant interaction of habitat and height $\left(F_{1,12}=2.427\right.$, $\mathrm{p}=0.145)$. Missing data due to lost collectors in the kelp bed at Little Duck Island in 1994 limited betweensite comparisons to the barrens. There was no signifi-

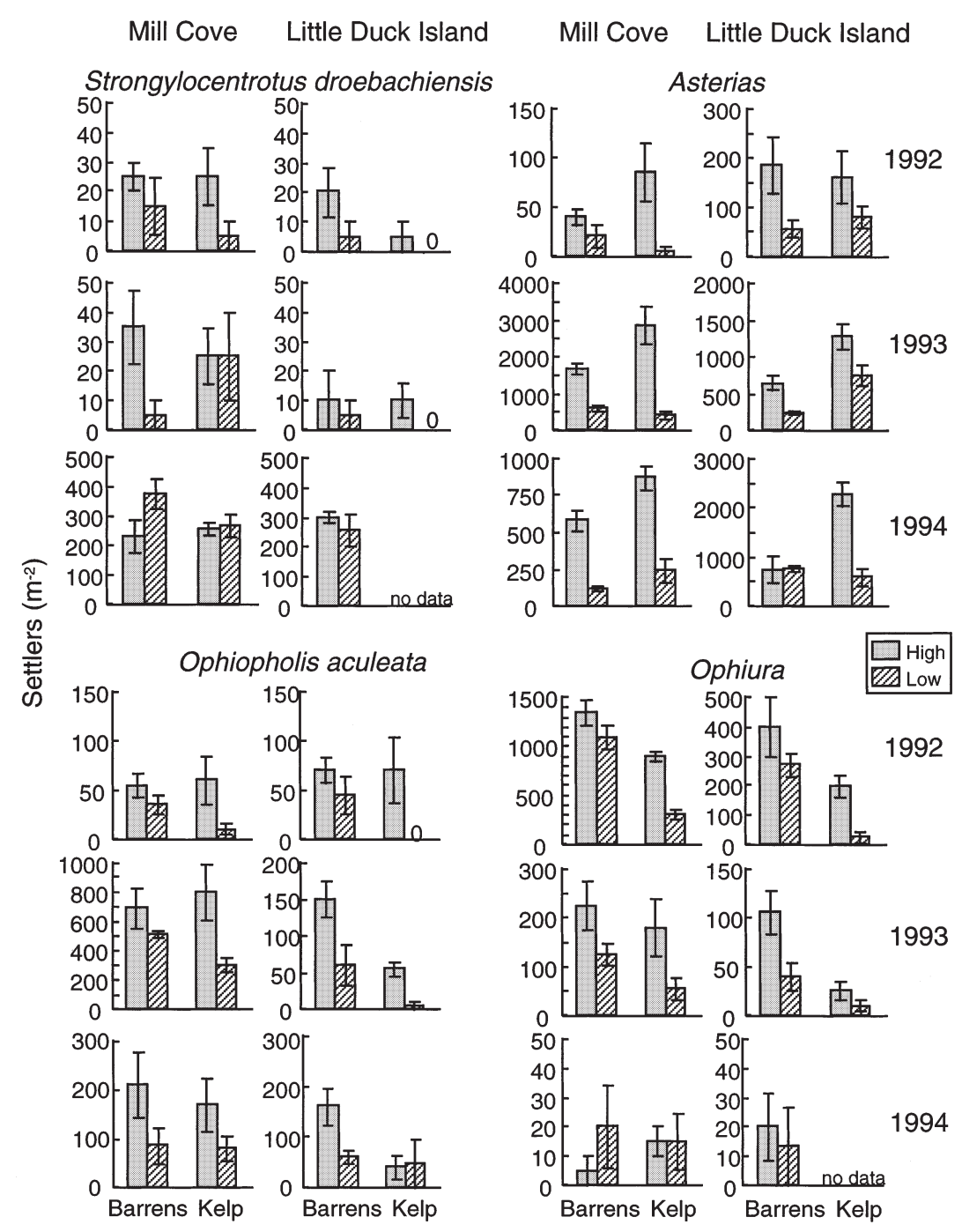

Fig. 2. Strongylocentrotus droebachiensis, Asterias spp., Ophiopholis aculeata and Ophiura spp. Mean $( \pm \mathrm{SE})$ density of settlers sampled in 4 replicate collectors at 2.3 and $0.2 \mathrm{~m}$ off bottom (high and low) in 2 habitats (kelp bed and barrens) during the bi-weekly interval of peak settlement for each genus/species in each year (1992 to 1994) at Mill Cove and Little Duck Island. Plots with no data are due to lost collectors during peak settlement. 
cant effect of site $\left(F_{1,10}=0.267, \mathrm{p}=0.617\right)$, or height $\left(F_{1,10}=0.966, \mathrm{p}=0.349\right)$, or interaction of height and site $\left(F_{1,10}=3.671, \mathrm{p}=0.084\right)$.

Settlement of the asteroids Asterias spp. was highly variable at both sites in all years, resulting in a significant 4 -way interaction of year, habitat, height and site (Fig. 2, Table 1). Post-hoc comparisons indicate greater settlement in 1993 and 1994 than in 1992, but between-site differences were significant in only 2 cases ('barrens low' in 1994, 'kelp low' in 1992). Settlement tended to be greater in high than in low collectors, particularly at Mill Cove. With the exception of Little Duck Island in 1992, settlement of Asterias spp. in high collectors was consistently greater above the kelp bed than above the barrens. However, this difference was statistically significant in only 1 case (Little Duck Island in 1994). At Mill Cove, a second pulse of settlement occurred at the end of the sampling period in September/October 1994. Again, settlement was greater in the high than in the low collectors $\left(F_{1,12}=14.453, \mathrm{p}=0.003\right)$, but there was no significant difference between habitats $\left(F_{1,12}<0.001\right.$, $\mathrm{p}=0.993)$ and no interaction of these factors $\left(F_{1,12}=\right.$ $0.084, p=0.776)$.
The ophiuroid Ophiopholis aculeata settled in significantly greater numbers in high than in low collectors, and there were no interactions between collector height and any of the other factors (Fig. 2, Table 2). However, there were significant 2-way interactions between year and site and between habitat and site. Settlement (averaged over habitats and heights) differed between years $(1993>1994>1992)$ at Mill Cove but not at Little Duck Island, and was greater at Mill Cove than Little Duck Island in 1993 but not in 1992 or 1994. Also, settlement (averaged over years and heights) was greater in the barrens than in the kelp bed at Little Duck Island, and greater in both habitats at Mill Cove than Little Duck Island.

Settlement of the ophiuroids Ophiura spp. decreased over the $3 \mathrm{yr}$ to very low numbers in 1994. ANOVA of settlement in 1992 and 1993 indicated a significant 3-way interaction between year, habitat and height and a 2-way interaction between year and site (Fig. 2, Table 3). Settlement (averaged over habitats, heights and sites) was greater in 1992 than in 1993, and greater at Mill Cove than Little Duck Island in both years. Settlement in low collectors (averaged over sites) was greater in the barrens than in the kelp

Table 1. Asterias spp. Results of 4-factor ANOVA and Tukey's HSD test for settlement at Mill Cove and Little Duck Island, sampled over 3 yr in 2 habitats (barrens, kelp bed) at 2 heights (high, low). Only statistically significant post-hoc comparisons are presented, with levels increasing in magnitude; values with common underlining do not differ significantly $(\alpha=0.05)$. Data are logtransformed $(\ln [x+1])$. MC: Mill Cove, LD: Little Duck Island, K: kelp bed, B: barrens, H: high, L: low

\begin{tabular}{|c|c|c|c|c|c|}
\hline Source & $\mathrm{df}$ & SS & MS & $F$ & $\mathrm{p}$ \\
\hline Year & 2 & 105.859 & 52.935 & 248.804 & 0.0001 \\
\hline Habitat & 1 & 2.664 & 2.664 & 12.522 & 0.0007 \\
\hline Height & 1 & 23.233 & 23.233 & 109.198 & 0.0001 \\
\hline Site & 1 & 4.778 & 4.778 & 22.457 & 0.0001 \\
\hline Year $\times$ Habitat & 2 & 0.814 & 0.407 & 1.913 & 0.1550 \\
\hline Year $\times$ Height & 2 & 0.351 & 0.175 & 0.824 & 0.4428 \\
\hline Year $\times$ Site & 2 & 10.689 & 5.345 & 25.121 & 0.0001 \\
\hline Habitat $\times$ Height & 1 & 1.136 & 1.136 & 5.341 & 0.0237 \\
\hline Habitat $\times$ Site & 1 & 0.701 & 0.701 & 3.296 & 0.0736 \\
\hline Height $\times$ Site & 1 & 2.311 & 2.311 & 10.862 & 0.0015 \\
\hline Year $\times$ Habitat $\times$ Height & 2 & 0.441 & 0.221 & 1.037 & 0.3596 \\
\hline Year $\times$ Habitat $\times$ Site & 2 & 0.846 & 0.423 & 1.989 & 0.1443 \\
\hline Year $\times$ Height $\times$ Site & 2 & 0.526 & 0.263 & 1.237 & 0.2963 \\
\hline Habitat $\times$ Height $\times$ Site & 1 & 0.107 & 0.107 & 0.502 & 0.4809 \\
\hline Year $\times$ Habitat $\times$ Height $\times$ Site & 2 & 3.148 & 1.574 & 7.399 & 0.0012 \\
\hline Residual & 72 & 15.318 & 0.213 & & \\
\hline Year & Habitat & Height & Site & & \\
\hline MCKH: $92 \underline{9493}$ & LDH94: B K & MCB94: L H & BL94: MC LD & & \\
\hline MCKL: $92 \underline{9493}$ & & MCK92: L H & KL92: MC LD & & \\
\hline МCBH: $92 \underline{9493}$ & & MCK93: L H & & & \\
\hline MCBL: 929493 & & MCK94: L H & & & \\
\hline LDKH: $92 \underline{9394}$ & & LDK94: L H & & & \\
\hline \multicolumn{6}{|l|}{ LDKL: $92 \underline{9493}$} \\
\hline LDBH: $\underline{929493}$ & & & & & \\
\hline LDBL: $92 \overline{9394}$ & & & & & \\
\hline
\end{tabular}


Table 2. Ophiopholis aculeata. Results of 4-factor ANOVA and Tukey's HSD test for settlement at Mill Cove and Little Duck Island, sampled over 3 yr in 2 habitats (barrens, kelp bed) at 2 heights (high, low). Further details as in legend to Table 1

\begin{tabular}{|c|c|c|c|c|c|}
\hline Source & df & SS & MS & $F$ & $\mathrm{p}$ \\
\hline Year & 2 & 26.866 & 13.433 & 44.783 & 0.0001 \\
\hline Habitat & 1 & 6.080 & 6.080 & 20.268 & 0.0001 \\
\hline Height & 1 & 11.835 & 11.835 & 39.456 & 0.0001 \\
\hline Site & 1 & 17.897 & 17.897 & 59.663 & 0.0001 \\
\hline Year $\times$ Habitat & 2 & 0.034 & 0.017 & 0.057 & 0.9450 \\
\hline Year $\times$ Height & 2 & 0.094 & 0.047 & 0.157 & 0.8546 \\
\hline Year $\times$ Site & 2 & 19.010 & 9.505 & 31.688 & 0.0001 \\
\hline Habitat $\times$ Height & 1 & 0.368 & 0.368 & 1.226 & 0.2719 \\
\hline Habitat $\times$ Site & 1 & 2.365 & 2.365 & 7.885 & 0.0065 \\
\hline Height $\times$ Site & 1 & 0.129 & 0.129 & 0.430 & 0.5142 \\
\hline Year $\times$ Habitat $\times$ Height & 2 & 1.326 & 0.663 & 2.211 & 0.1172 \\
\hline Year $\times$ Habitat $\times$ Site & 2 & 0.438 & 0.219 & 0.729 & 0.4859 \\
\hline Year $\times$ Height $\times$ Site & 2 & 0.534 & 0.267 & 0.891 & 0.4149 \\
\hline Habitat $\times$ Height $\times$ Site & 1 & 0.027 & 0.027 & 0.091 & 0.7640 \\
\hline Year $\times$ Habitat $\times$ Height $\times$ Site & 2 & 0.190 & 0.095 & 0.318 & 0.7290 \\
\hline Residual & 70 & 20.997 & 0.300 & & \\
\hline Year & Habitat & Height & Site & & \\
\hline MC: 929493 & LD: K B & All pooled: L H & $\begin{array}{l}\text { 93: LD MC } \\
\text { K: LD MC } \\
\text { B: LD MC }\end{array}$ & & \\
\hline
\end{tabular}

Table 3. Ophiura spp. Results of 4-factor ANOVA and Tukey's HSD test for settlement at Mill Cove and Little Duck Island, sampled over 3 yr in 2 habitats (barrens, kelp bed) at 2 heights (high, low). Further details as in legend to Table 1

\begin{tabular}{|c|c|c|c|c|c|}
\hline Source & $\mathrm{df}$ & SS & MS & $F$ & $\mathrm{p}$ \\
\hline Year & 1 & 33.824 & 33.824 & 155.674 & 0.0001 \\
\hline Habitat & 1 & 12.118 & 12.118 & 55.772 & 0.0001 \\
\hline Height & 1 & 8.749 & 8.749 & 40.267 & 0.0001 \\
\hline Site & 1 & 26.294 & 26.294 & 121.015 & 0.0001 \\
\hline Year $\times$ Habitat & 1 & 0.633 & 0.633 & 2.915 & 0.0942 \\
\hline Year $\times$ Height & 1 & 0.106 & 0.106 & 0.487 & 0.4885 \\
\hline Year $\times$ Site & 1 & 1.440 & 1.440 & 6.628 & 0.0132 \\
\hline Habitat $\times$ Height & 1 & 1.439 & 1.439 & 6.621 & 0.0132 \\
\hline Habitat $\times$ Site & 1 & 0.683 & 0.683 & 3.145 & 0.0825 \\
\hline Height $\times$ Site & 1 & 0.056 & 0.056 & 0.259 & 0.6133 \\
\hline Year $\times$ Habitat $\times$ Height & 1 & 1.366 & 1.366 & 6.286 & 0.0156 \\
\hline Year $\times$ Habitat $\times$ Site & 1 & 0.021 & 0.021 & 0.097 & 0.7570 \\
\hline Year $\times$ Height $\times$ Site & 1 & 0.234 & 0.234 & 1.077 & 0.3046 \\
\hline Habitat $\times$ Height $\times$ Site & 1 & 0.017 & 0.017 & 0.080 & 0.7786 \\
\hline Year $\times$ Habitat $\times$ Height $\times$ Site & 1 & 0.610 & 0.610 & 2.806 & 0.1004 \\
\hline Residual & 48 & 10.429 & 0.217 & & \\
\hline Year & Habitat & Height & Site & & \\
\hline BH: 9392 & L92: K B & K92: L H & 92: LD MC & & \\
\hline BL: 9392 & & & 93: LD MC & & \\
\hline \multicolumn{6}{|l|}{ KH: 9392} \\
\hline \multicolumn{6}{|l|}{ KL: 9392} \\
\hline \multicolumn{6}{|l|}{ MC: 9392} \\
\hline LD: 9392 & & & & & \\
\hline
\end{tabular}


beds in 1992 but not in 1993, and greater in high than in low collectors in the kelp bed in 1992. Ophiura spp., the only species that settled in abundance at Mill Cove in 1992, also was used to test the effect of station position within habitats in a nested ANOVA. The analysis showed that the effect of position, the nested factor, was not significant (kelp bed: $F_{3,16}=$ 0.456, $\mathrm{p}=0.717$; barrens: $F_{3,16}=2.021, \mathrm{p}=0.152$ ) nor was the interaction of height and position (kelp bed: $F_{3,16}=0.706, \mathrm{p}=0.562 ;$ barrens: $F_{3,16}=1.150, \mathrm{p}=$ 0.359), indicating little variation among collector stations within each habitat.

\section{Effect of sampling frequency}

At Mill Cove, sampling at $3 \mathrm{~d}$ intervals showed that most settlement of Ophiopholis aculeata and Ophiura spp. during the $\sim 2$ wk settlement period in 1993 occurred within 6 d (see also Balch et al. 1999). A comparison of settlement of these ophiuroids summed over 5 successive $3 \mathrm{~d}$ intervals with that recorded over the same 15 d interval (Fig. 3) indicated no significant effect of sampling frequency (O. aculeata: $F_{1,24}=3.543$, $\mathrm{p}=0.072$; Ophiura spp.: $\left.F_{1,24}=0.488, \mathrm{p}=0.492\right)$ or interaction of sampling frequency with habitat $\left(F_{1,24}=\right.$

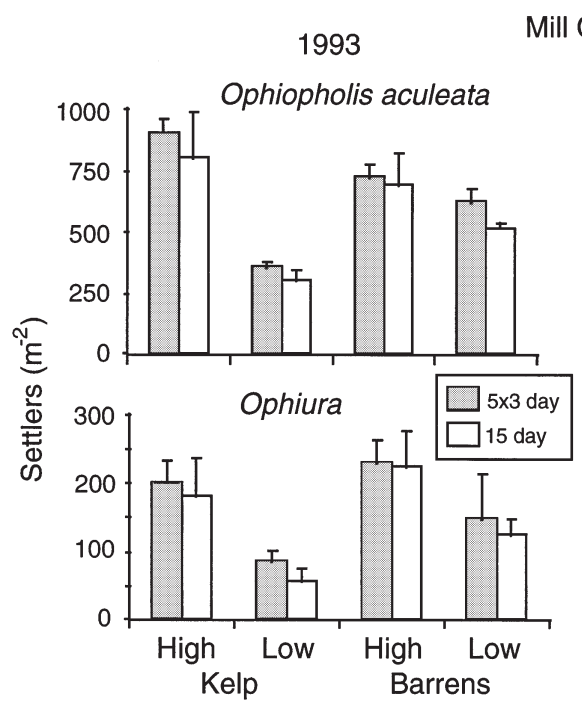

Mill Cove

1994

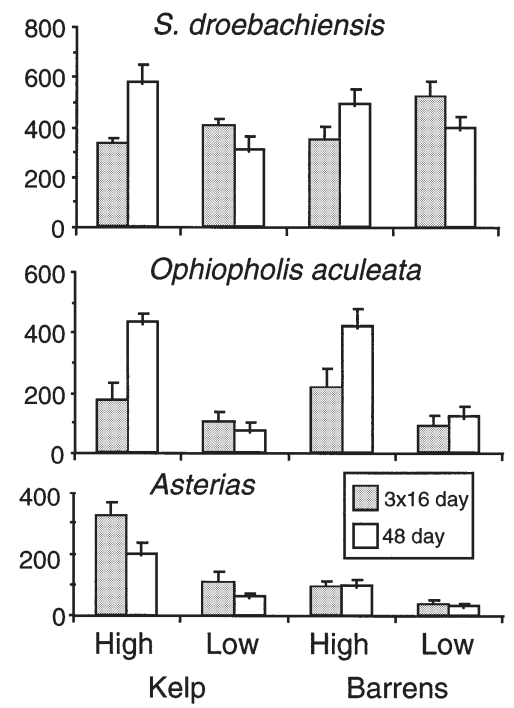

Fig. 3. Strongylocentrotus droebachiensis, Asterias spp., Ophiopholis aculeata and Ophiura spp. Mean (+SE) density of echinoderm settlers in 4 replicate collectors in each of 4 sampling strata (kelp high, kelp low, barrens high, barrens low) at Mill Cove over a 15 d period in July/August 1993 and a 48 d period in June/July 1994. In 1993, settlement of $O$. aculeata and Ophiura spp. summed over 5 successive $3 \mathrm{~d}$ $(5 \times 3 \mathrm{~d})$ intervals is compared to a single $15 \mathrm{~d}$ measurement over the same period. In 1994, settlement of $S$. droebachiensis, O. aculeata and Asterias spp. summed over 3 successive $16 \mathrm{~d}(3 \times 16 \mathrm{~d})$ intervals is compared to a single $48 \mathrm{~d}$ measurement over the same period $\left.0.081, \mathrm{p}=0.778 ; F_{1,24}=0.025, \mathrm{p}=0.877\right)$ or height $\left(F_{1,24}=\right.$ $\left.0.090, \mathrm{p}=0.767 ; F_{1,24}=0.059, \mathrm{p}=0.811\right)$. A comparison of settlement of Strongylocentrotus droebachiensis and $O$. aculeata summed over 3 successive 16 d intervals to that recorded over the same 48 d interval in 1994 (Fig. 3) indicated a significant interaction of sampling frequency and height $\left(S\right.$. droebachiensis: $F_{1,24}=$ 16.097, $\mathrm{p}=0.001 ; O$. aculeata: $\left.F_{1,24}=12.326, \mathrm{p}=0.002\right)$. Settlement for both species (averaged over habitats) was greater in high than in low collectors in the $48 \mathrm{~d}$ sample but not in the summed $16 \mathrm{~d}$ samples, and greater in the $48 \mathrm{~d}$ sample than in the summed $16 \mathrm{~d}$ ples in high collectors but not in low collectors. Ophiura spp. settled in low numbers during 1994, and most settlement of Asterias spp. occurred later in the year (Fig. 3). For both species, there was no significant effect of sampling frequency (Ophiura spp.: $F_{1,24}=$ $0.800, \mathrm{p}=0.380$; Asterias spp.: $\left.F_{1,24}=3.960, \mathrm{p}=0.058\right)$ nor significant interaction with habitat $\left(F_{1,24} \approx 0, \mathrm{p} \approx 1\right.$; $\left.F_{1,24}=3.960, \mathrm{p}=0.058\right)$ or height $\left(F_{1,24}=0.200, \mathrm{p}=\right.$ $\left.0.659 ; F_{1,24}=0.615, \mathrm{p}=0.441\right)$.

The fouling index after $48 \mathrm{~d}$ shows that high collectors were more fouled than low collectors $\left(F_{1,12}=\right.$ 151.742, p < 0.001), collectors in the kelp bed were more fouled than those in the barrens $\left(F_{1,12}=9.484\right.$, $\mathrm{p}=0.010$ ), and that there was no significant interaction of habitat and collector height $\left(F_{1,12} \approx 0, \mathrm{p} \approx 1\right)$ (Fig. 4). This difference in fouling, in part, could be due to differences in the abundance of herbivorous amphipods. ANOVA of amphipod abundance in the $48 \mathrm{~d}$ sample showed greater numbers in low than in high collectors $\left(F_{1,12}=14.878, \mathrm{p}=0.002\right)$, no difference in abundance between habitats $\left(F_{1,12}=1.653, \mathrm{p}=\right.$ 0.223 ), and no interaction of habitat and collector height $\left(F_{1,12}=\right.$ 1.653, $\mathrm{p}=0.223$ ) (Fig. 4). To further examine the relationship between fouling and settlement, and between amphipod abundance and fouling, we used regression analysis. Settlement of both Strongylocentrotus droebachiensis $\left(\mathrm{r}^{2}=0.280\right.$, $\mathrm{p}=0.035$ ) and Ophiopholis aculeata $\left(\mathrm{r}^{2}=0.775, \mathrm{p}<0.001\right)$ was positively related to fouling in the 48 d sample, but there was no significant relationship in each of the 16 d samples $(p>0.2)$. Fouling was negatively related to amphipod abundance in the $48 \mathrm{~d}$ sample $\left(\mathrm{r}^{2}=\right.$ 0.367, $\mathrm{p}=0.013$ ). 


\section{Temporal and spatial patterns of recruitment}

Size distributions of Strongylocentrotus droebachiensis from 1993 to 1995 were skewed towards juvenile size classes $(\leq 16 \mathrm{~mm})$, reflecting recent recruitment (Fig. 5). In 1995 in particular, echinoid populations in both habitats at each site were dominated by recruits from the previous year $(\leq 8 \mathrm{~mm})$. Analysis of recruit density indicated significant differences between years $\left(F_{2,85}=123.092, \mathrm{p}<0.001\right)$, habitats $\left(F_{1,85}=\right.$ $76.000, \mathrm{p}<0.001)$ and sites $\left(F_{1,85}=34.315, \mathrm{p}<0.001\right)$ (Fig. 6) but no significant 2-way (year $\times$ habitat: $F_{2,85}=$ $1.934, \mathrm{p}=0.151$; year $\times$ site: $F_{2,85}=1.235, \mathrm{p}=0.296$; habitat $\times$ site: $\left.F_{1,85}=0.033, \mathrm{p}=0.856\right)$ or 3-way $\left(F_{2,85}=\right.$ $2.409, \mathrm{p}=0.096$ ) interactions. Recruitment of $S$. droebachiensis was greater in barrens than in kelp beds, greater at Mill Cove than Little Duck Island, and greater in 1995 than 1994 (by an order of magnitude) and in 1994 than 1993 (Fig. 6).

Size distributions of Asterias spp. were heavily skewed towards juveniles $(\leq 10 \mathrm{~mm})$ in both habitats at each site in 1994 and 1995, and in the kelp bed at Little Duck Island in 1993 (Fig. 5). Analysis of recruit density indicated a 3-way interaction of year, habitat and site (Fig. 6, Table 4), largely because of differences in magnitude, rather than direction, of recruitment. Recruitment generally was greater in 1995 and 1994 than in 1993, greater in kelp beds than in barrens, and greater at Mill Cove than at Little Duck Island.

Size distributions of Ophiopholis aculeata were approximately normal at both sites in all years, but slightly skewed towards the smallest size classes ( $\leq 4 \mathrm{~mm})$ at Mill Cove in 1995 (Fig. 7). Modal size tended to be smaller at Mill Cove (4 to $6 \mathrm{~mm}$ ) than at Little Duck Island ( 7 to $9 \mathrm{~mm}$ ) between 1993 and 1995. Analysis of recruit density indicated significant differences between years $\left(F_{2,92}=11.726, \mathrm{p}<0.001\right)$ and sites $\left(F_{1,92}=19.807, \mathrm{p}<0.001\right)$, but not between habitats $\left(F_{1,92}=0.405, \mathrm{p}=\right.$ $0.526)$ (Fig. 7). There were no significant 2-way (year $\times$ habitat: $F_{2,92}=0.287$, $\mathrm{p}=0.751$; year $\times$ site: $F_{2,92}=0.713, \mathrm{p}=$ 0.493 ; habitat $\times$ site: $F_{1,92}=0.217, \mathrm{p}=$ $0.643)$ or 3-way $\left(F_{2,92}=0.624, \mathrm{p}=0.538\right)$ interactions. Recruitment was greater at Mill Cove than at Little Duck Island and greater in 1995 than in 1994, and in 1994 than in 1993.

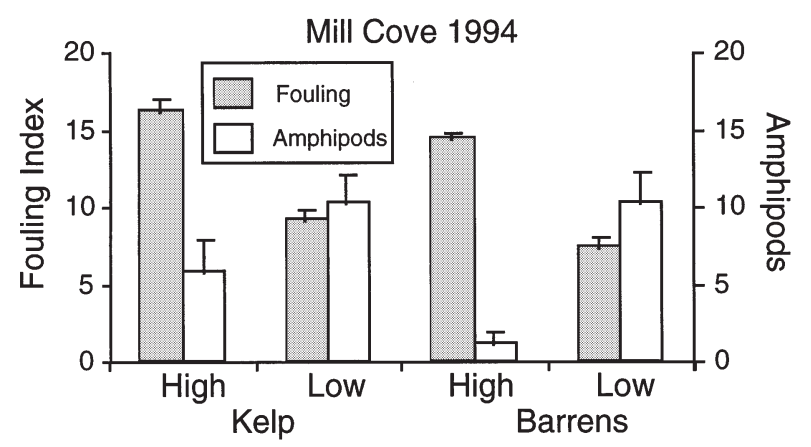

Fig. 4. Mean (+SE) fouling index and density of amphipods in 4 replicate collectors in each of 4 sampling strata (kelp high, kelp low, barrens high, barrens low) over a $48 \mathrm{~d}$ period in June/July 1994 at Mill Cove

Ophiura robusta occurred in low numbers at both sites and with approximately normal size distributions (Fig. 7). Recruits were rare or absent between 1993 and 1995, precluding any statistical analysis (Fig. 6).

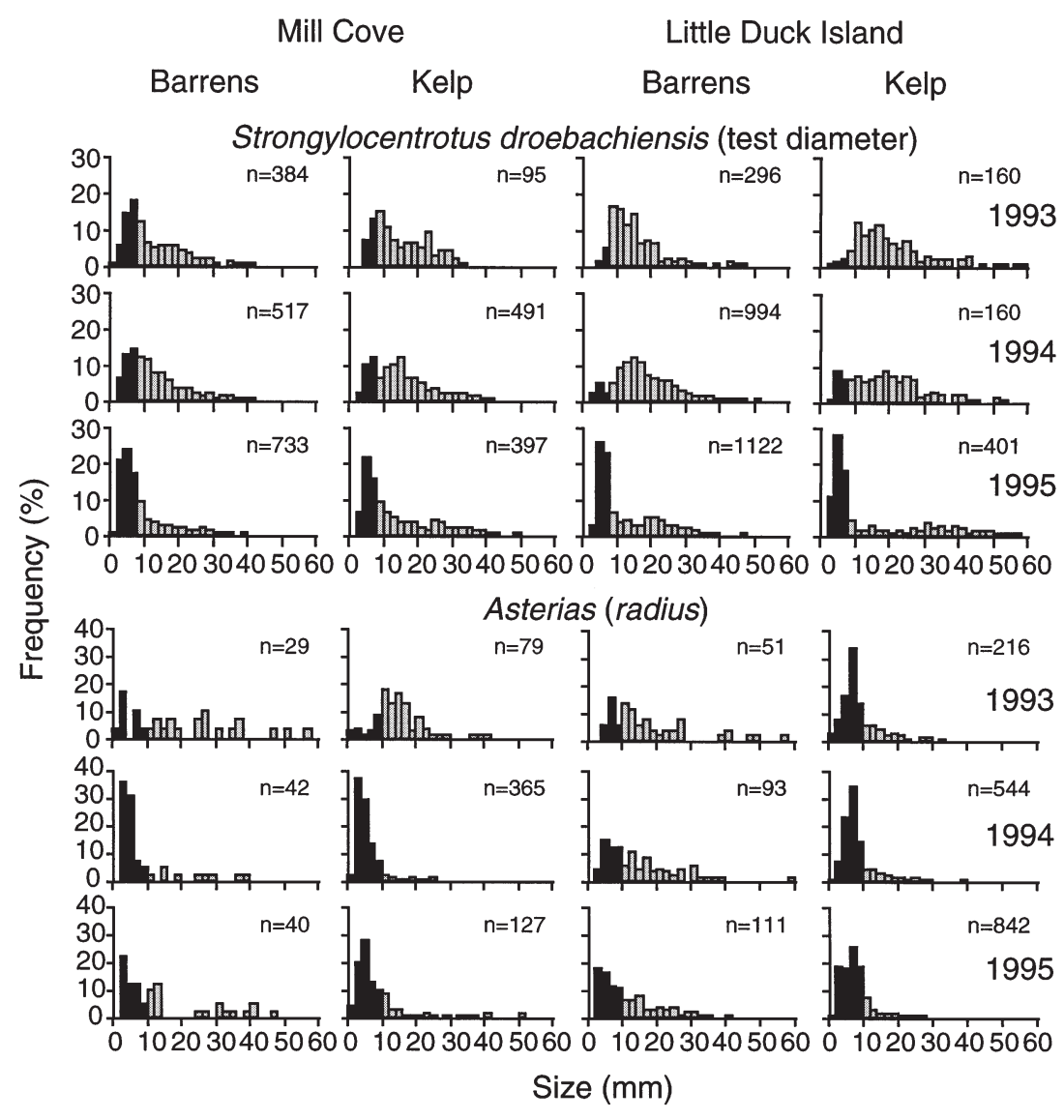

Fig. 5. Strongylocentrotus droebachiensis and Asterias (A. vulgaris and A. forbesi combined). Size-frequency distributions of echinoderms collected in $1.0 \mathrm{~m}^{2}$ quadrats ( $\mathrm{n}=4$ to 10 ) in 2 habitats (kelp bed and barrens) between July and October 1993 to 1995 at Mill Cove and Little Duck Island. Recruits are shaded black 

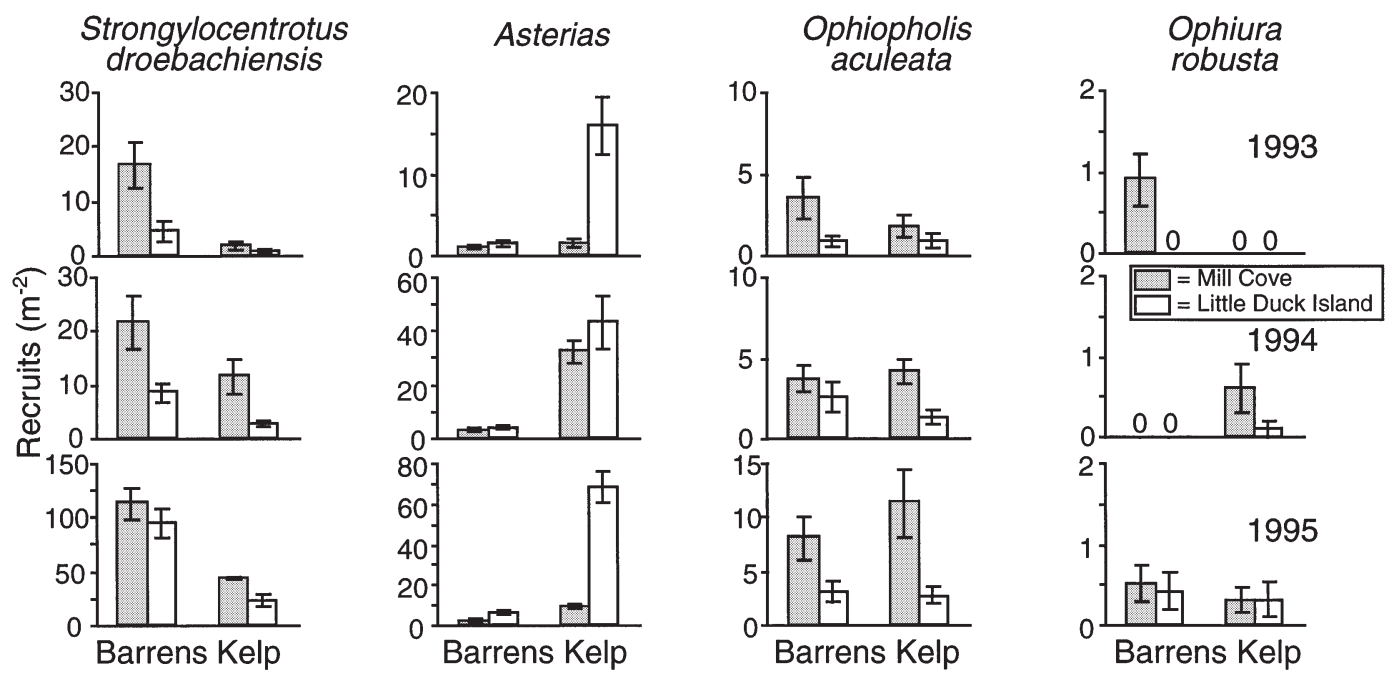

Fig. 6. Strongylocentrotus droebachiensis, Asterias spp., Ophiopholis aculeata and Ophiura robusta. Mean ( \pm SE) density of recruits collected in $1.0 \mathrm{~m}^{2}$ quadrats $(\mathrm{n}=4$ to 10) in 2 habitats (kelp bed and barrens) between July and October 1993 to 1995 at Mill Cove and Little Duck Island

\section{Relationship between settlement and recruitment}

We used regression analyses to examine the relationship between mean settlement in the low collectors during the $\sim 2$ wk peak each year (1992 to 1994) and mean recruitment $\sim 1$ yr later (1993 to 1995) from each combination of site, habitat and year (Fig. 8). Logarithmic transformation of the means $(\log [x+1])$ strengthened the relationship in 3 out of 4 cases (for Ophiura spp. it remained non-significant). For Strongylocentrotus droebachiensis, recruitment strongly reflected set- tlement in the previous year: $84 \%$ of the variation in recruitment is explained by the variation in settlement. Low settlement of echinoids in 1992 and 1993 resulted in low recruitment in the subsequent years, but a large settlement event in 1994 resulted in high recruit density in 1995 at both sites and in both habitats. Although settlement and recruitment rates of Asterias spp. were more variable, $42 \%$ of the variation in recruitment is explained by variation in settlement. Recruitment of Ophiopholis aculeata was consistently low, although settlement varied by almost 3 orders of magnitude.

Table 4. Asterias spp. Results of 3-factor ANOVA and Tukey's HSD test for recruitment at Mill Cove and Little Duck Island, sampled over 3 yr in 2 habitats (barrens, kelp bed). Further details as in legend to Table 1

\begin{tabular}{|c|c|c|c|c|c|}
\hline Source & $\mathrm{df}$ & SS & MS & $F$ & $\mathrm{p}$ \\
\hline Year & 2 & 43.304 & 21.652 & 56.190 & 0.0001 \\
\hline Habitat & 1 & 80.524 & 80.524 & 208.970 & 0.0001 \\
\hline Site & 1 & 22.188 & 22.188 & 57.581 & 0.0001 \\
\hline Year $\times$ Habitat & 2 & 6.357 & 3.179 & 8.249 & 0.0005 \\
\hline Year $\times$ Site & 2 & 7.943 & 3.972 & 10.307 & 0.0001 \\
\hline Habitat $\times$ Site & 1 & 5.142 & 5.142 & 13.344 & 0.0004 \\
\hline Year $\times$ Habitat $\times$ Site & 2 & 3.203 & 1.601 & 4.156 & 0.0182 \\
\hline Residual & 48 & 41.617 & 0.385 & & \\
\hline Year & Habitat & Site & & & \\
\hline MCK: 939495 & MC94: B K & K93: LD MC & & & \\
\hline LDB: 939495 & MC95: B K & B95: LD MC & & & \\
\hline \multirow[t]{3}{*}{ LDK: $93 \underline{9495}$} & LD93: B K & K95: LD MC & & & \\
\hline & LD94: B K & & & & \\
\hline & LD95: B K & & & & \\
\hline
\end{tabular}




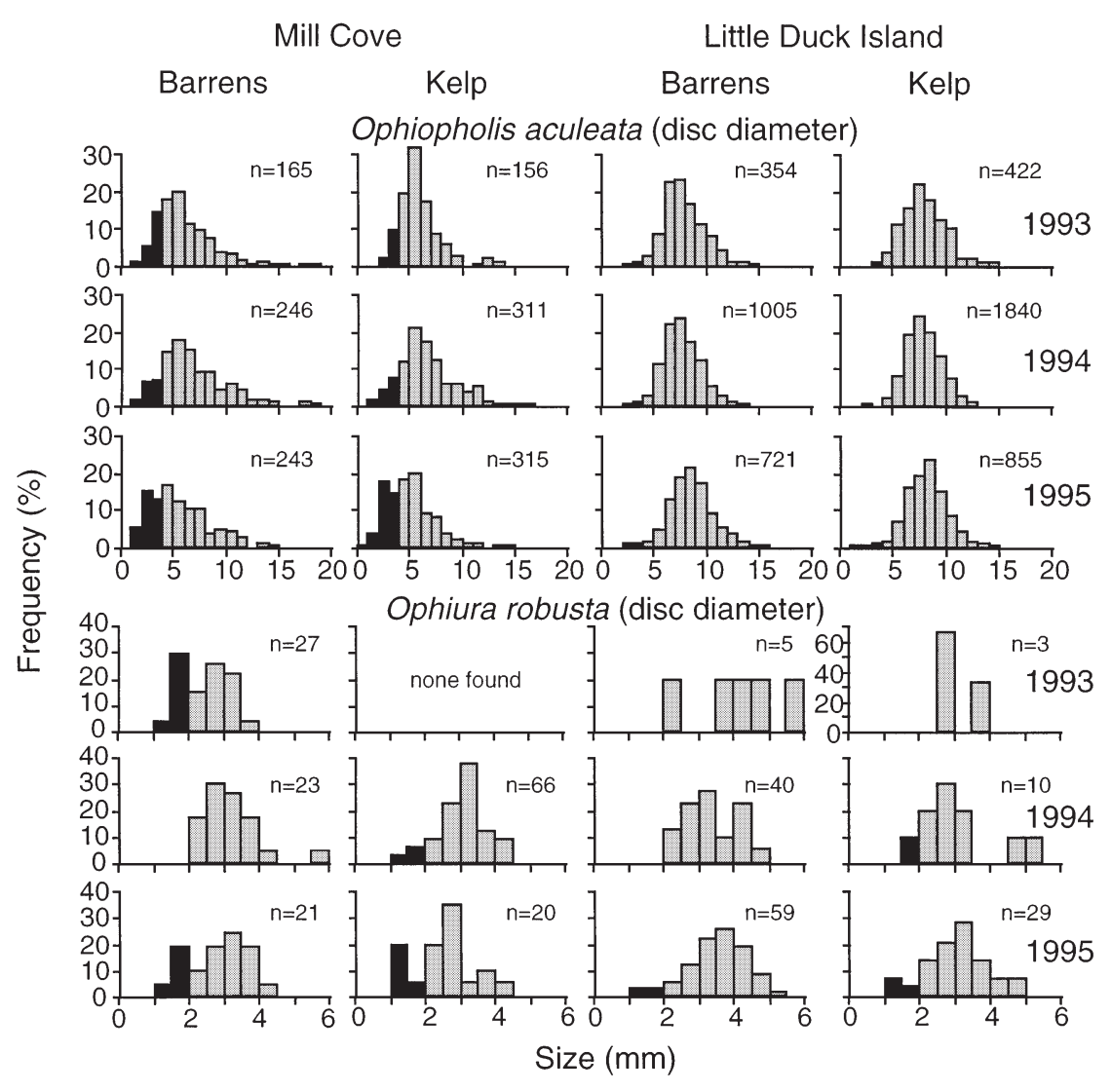

Fig. 7. Ophiopholis aculeata and Ophiura robusta. Size-frequency distributions of echinoderms collected in $1.0 \mathrm{~m}^{2}$ quadrats ( $\mathrm{n}=6$ to 10) in 2 habitats (kelp bed and barrens) between July and October 1993 to 1995 at Mill Cove and Little Duck Island. Recruits are shaded black

Nevertheless, $38 \%$ of the variation in recruitment of this ophiuroid is explained by variation in settlement. Ophiura spp. exhibited a similar variation in settlement as $O$. aculeata, but recruits were so rare each year that there was no significant relationship between recruitment and settlement.

\section{DISCUSSION}

\section{Temporal patterns of settlement}

Timing of settlement of echinoderms in our study differed consistently among species in relation to differences in timing of spawning and larval development. Almost all settlement of Strongylocentrotus droebachiensis occurred in July, but low numbers of settlers were found as late as October. S. droebachiensis spawns in March/April at both sites (Meidel \& Scheibling 1998), and laboratory-reared larvae settle 4 to 22 wk post- fertilization at temperatures within the range they experience along the coast of Nova Scotia (Strathmann 1987, Pearce \& Scheibling 1990, Meidel et al. 1999). Settlement of Asterias spp. at our sites was variable among years, occurring from late July to early October, which may in part be explained by the occurrence of 2 species. In New England and Prince Edward Island, A. vulgaris spawns from April to July, whereas A. forbesi spawns in July/August (Smith 1940, Boolootian 1966, Menge 1986). Thus, the second peak in settlement at Mill Cove in September/October 1994 could be that of $A$. forbesi. Settlement of $A$. forbesi over a $24 \mathrm{yr}$ period in Long Island Sound occurred between June and September each year (Loosanoff 1964). The ophiuroids Ophiopholis aculeata and Ophiura spp. settled from July to early August each year. Spawning of $O$. aculeata occurs in April/May in Norway (Olsen 1943), and laboratoryreared larvae settle within 12 to 31 wk (Strathmann 1978). Ophiura sarsi spawns from March to June in Washington (Strathmann 1987), but Packer et al. (1994) suggest that deep-water populations of $O$. sarsi in the Gulf of Maine spawn year-round, with a peak from January to April. Thus, the summer/fall settlement peak that we observed for each echinoderm species along the Atlantic coast of Nova Scotia was consistent with their respective annual reproductive cycles and measured larval periods.

The infrequent occurrence of major settlement events observed in our study underscores their potential importance in determining population structure and abundance in this region. For most of the species that we measured, settlement was minimal during 1 or 2 out of the 3 yr of our study and, within each year, the majority of settlement occurred over a period of $2 \mathrm{wk}$ or less. For example, Strongylocentrotus droebachiensis settled in abundance only in the first 2 wk of July in 1994. In contrast, S. droebachiensis in the southern Gulf of Maine settle in large numbers each year in June and early July (Harris et al. 1994), and S. francis- 


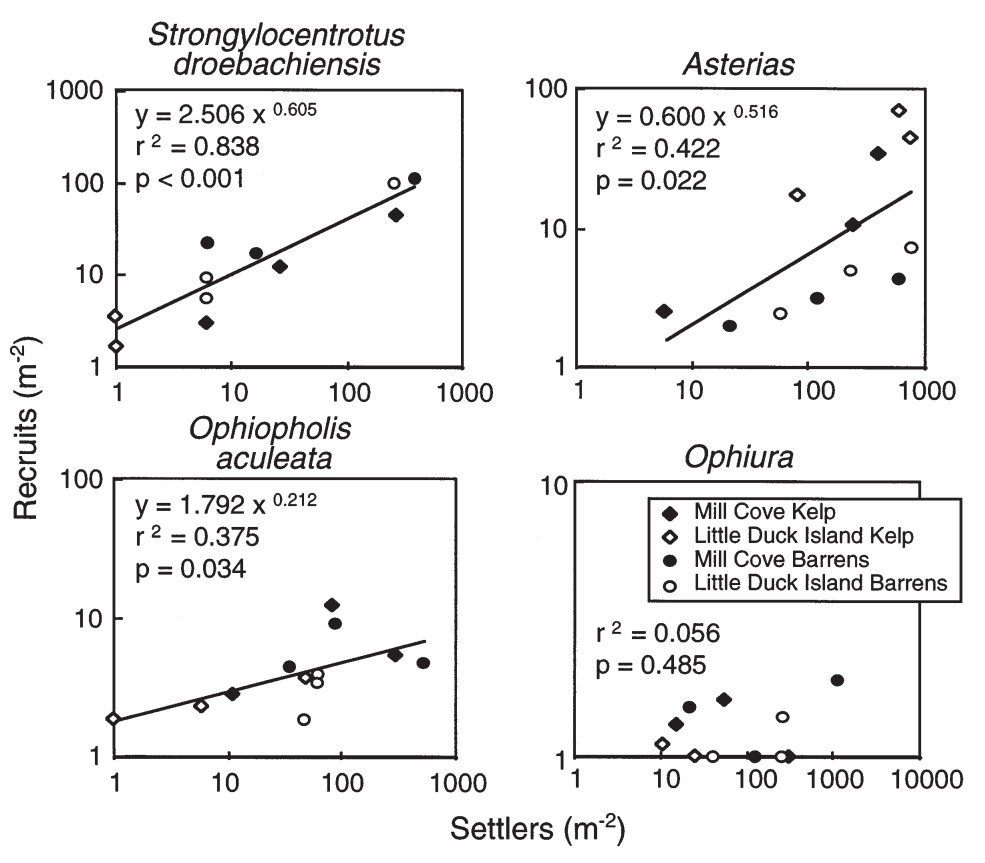

Fig. 8. Strongylocentrotus droebachiensis, Asterias spp., Ophiopholis aculeata and Ophiura spp. Relationship between mean settlement (1992 to 1994) and mean recruitment in subsequent years (1993 to 1995) measured in 2 habitats (kelp bed and barrens) at Mill Cove and Little Duck Island. Means are calculated from settlers sampled in 4 low collectors during the bi-weekly interval of peak settlement in each year (1992 to 1994) and from recruits collected from 4 to 10 quadrats of $1.0 \mathrm{~m}^{2}$ between July and October 1993 to 1995. Also shown are regression lines and exponential equations relating recruit density $(y)$ to settler density $(x)$ and associated $r^{2}$ and $p$ value of this relationship

canus and S. purpuratus in California and Oregon settle over a protracted period each year from December to July (Harrold et al. 1991, Ebert et al. 1994, Wing et al. 1995b, Miller \& Emlet 1997). Unlike S. droebachiensis, Asterias spp. settled in high but variable numbers each year of our study, which concurs with the longterm observations of Loosanoff (1964) on A. forbesi in Long Island Sound.

Variation in the magnitude of settlement between species and years at our sites suggests that large-scale environmental factors, such as fluctuations in sea temperature or shelf-scale upwelling events do not regulate settlement. Temperature is known to increase the rate of larval development (reviewed by Strathmann 1987), and higher than normal spring temperatures have been suggested to enhance settlement of Strongylocentrotus droebachiensis in Nova Scotia (Hart \& Scheibling 1988, Scheibling 1996). In our study, however, interannual variation in temperature alone cannot explain settlement patterns, because species with similar larval development and timing of settlement settled in greatest abundance in different years. For the same reason, shelf-scale upwelling and relaxation events, which periodically occur along the Atlantic coast of Nova Scotia in the summer (Petrie et al. 1987), are also not likely to regulate settlement, as has been suggested for echinoderm larvae in other systems (Johnson et al. 1984, Wing et al. 1995a,b, Miller \& Emlet 1997). Rather, differences between species in interannual settlement patterns may be related to differences in reproductive output and larval survival, which determine larval availability in a given year. Because the same interannual pattern was observed at both sites for each species, larval delivery probably is determined by hydrodynamic forcing at scales of at least 10 s of kilometres.

\section{Spatial patterns of settlement}

Although we detected few statistically significant differences between sites, settlement of echinoderms, and particularly of ophiuroids, tended to be greater at Mill Cove than Little Duck Island. This may be related to local differences in hydrodynamic conditions resulting in greater larval supply to Mill Cove. The predominant southwesterly flow along the Atlantic coast of Nova Scotia (Loder et al. 1997) suggests that larvae arriving at both sites probably originate from spawning populations to the northeast. Mill Cove is in a large semi-enclosed embayment characterised by a unidirectional counter-clockwise flow that may retain larvae (Heath 1973). In contrast, Little Duck Island is a more exposed site subjected to variable, wave-induced flows that are more likely to disperse than retain larvae supplied to the area. Similarly, Ebert \& Russel (1988) suggest that settlement of Strongylocentrotus purpuratus in California and Oregon is lower off capes and headlands which experience more upwelling than the more sheltered bays and coves in between. However, it should be noted that there are potentially many factors aside from hydrodynamic conditions which vary between sites and may account for the differences in settlement that we observed. Also, without replication of sites in each hydrodynamic region, we cannot discount the possibility that variability in settlement within regions may equal or even exceed that between regions. Further studies with replication at different spatial scales are required to elucidate the role of hydrodynamics in determining settlement patterns along this coast. 
Although settlement differed between kelp beds and barrens for some species, kelp beds did not exhibit a consistent or strong inhibitory effect on settlement. The ophiuroids Ophiopholis aculeata and Ophiura spp. showed a trend toward greater settlement in the barrens, whereas Asterias spp. settled in greater numbers above kelp beds (i.e., on high collectors). Unlike the other species, however, Asterias spp. recruits were observed on kelp fronds, suggesting that the kelp itself may filter out settlers, reducing the number available to settle within the bed (i.e., on low collectors). Our limited data on settlement of Strongylocentrotus droebachiensis indicate higher settlement on average in barrens at Mill Cove in 1994 (the only year of heavy settlement), although the difference was not statistically significant. This may have been due to insufficient power in our test of a habitat effect, resulting from low replication. We calculated that 12 replicates would have been required to conclude that the habitat effect we observed in low collectors (with $\mathrm{n}=4$ ) was statistically significant $(\alpha=0.05)$ assuming adequate power $(1-\beta=0.80)$. Previous studies comparing settlement of echinoids between kelp beds/forests and barrens also have yielded equivocal results (reviewed by Balch \& Scheibling in press). Regional differences in kelp morphology and kelp bed/forest structural complexity may account for some of these disparities. For example, kelp beds in Nova Scotia typically extend only 1 to $2 \mathrm{~m}$ above the bottom and probably do not deflect currents (and therefore incoming larvae) in the same way as the kelp forests of the northwest Pacific, where the canopy extends to the surface (Jackson \& Winant 1983, Dayton \& Tegner 1984, Harrold \& Pearse 1987).

Although echinoderm larvae generally are found near the surface (0 to $30 \mathrm{~m}$ depth) in nearshore waters (Rumrill 1988, Pedrotti \& Fenaux 1992, Miller \& Emlet 1997), there is little resolution of larval distribution within the surface layer. In our study, echinoderm larvae generally settled in greater numbers in high than in low collectors. High collectors were intended to measure larval supply independently of habitat effects, including decreased flow in the benthic boundary layer (Eckman et al. 1989). However, the kelp bed at each site is 2 to $3 \mathrm{~m}$ shallower than the barrens, which may have resulted in high collectors sampling different strata of the water column containing different numbers of larvae. Furthermore, collectors closer to the surface and exposed to more light become more fouled, which may enhance settlement in shallower collectors (see 'Sampling frequency' below). Therefore, between-habitat differences in settlement in high collectors (e.g., Asterias spp.) may simply reflect depth-related differences in larval abundance or degree of collector fouling. Settlement in low collec- tors is less likely to be affected by small differences in bottom depth, since these were further from the surface and in a region where settlement is more likely to be influenced by bottom features (reviewed by Butman 1987).

\section{Sampling frequency}

Comparisons of settlement measured at shorter or longer intervals show that our bi-weekly samples measured settlement with minimal confounding by postsettlement processes or temporal changes in collector efficacy. Because our collectors were isolated from the substratum and excluded many potential predators, early post-settlement mortality or migration probably was minimised. Thus, although most settlement of Ophiopholis aculeata and Ophiura spp. in 1993 occurred over 6 d within a 2 wk period (Balch et al. 1999), there was no difference in settlement measured every $3 \mathrm{~d}$ for $15 \mathrm{~d}$ compared to a single measurement over the whole interval. In contrast, settlement of Strongylocentrotus droebachiensis and $O$. aculeata pooled over 3 successive $16 \mathrm{~d}$ intervals was significantly less than that measured over the same $48 \mathrm{~d}$ interval. This may be because of fouling during long deployment times, which enhances the quality of the settlement surface or its ability to passively trap settlers. Greater fouling in high than in low collectors, and in kelp beds than in barrens may be related to the difference in depth between habitats (see 'Spatial patterns of settlement' above) and/or to the greater number of herbivorous amphipods in low collectors, which reduced algal fouling. Artifactual effects of sampling design, such as the presence of migrating or settling grazers or predators in collectors (Harrold et al. 1991) or differential light availability as a function of depth or shading (Eckman \& Duggins 1991), may bias results and limit comparability between studies, or between locations in the same studies.

\section{Temporal and spatial patterns of recruitment}

Interannual patterns of recruitment of echinoderms in our study are similar to patterns of settlement in the previous year, with major recruitment events occurring in only 1 or 2 out of 3 yr. Sporadic recruitment has been documented for many species of echinoderms in various geographic regions, and is often attributed to variable settlement (reviewed by Ebert 1983, Balch \& Scheibling in press). Although we recorded recruitment of all species in all years, it is these strong recruitment events which probably make a disproportionate contribution to overall popu- 
lation abundance and demographic structure (see also López et al. 1998).

Species-specific differences in recruitment between kelp beds and barrens probably are a result of differences in both settlement and post-settlement mortality between habitats. Recruitment of Strongylocentrotus droebachiensis was $\sim 2$ times greater in barrens than in kelp beds, although there was no statistically significant difference between habitats in settlement (but see 'Spatial patterns in settlement' above). This suggests that juveniles suffered higher mortality in kelp beds. We observed the opposite effect of habitat on Asterias spp., for which recruitment was up to an order of magnitude greater in kelp beds than barrens. Settlement of asteroids also tended to be greater in and above kelp beds, but differences between habitats were not as great (the ratio of recruits in kelp beds relative to barrens, pooled over sites and years, is 9.4; the ratio for settlers, pooled over sites, years and collector heights, is 1.7), suggesting higher post-settlement mortality in the barrens. This also appears to be the case for Ophiopholis aculeata, since there was no difference in recruitment of this ophiuroid between habitats but settlement was greater in the barrens. Kelp creates structure that may offer spatial refuges from predation to juveniles of some species, such as Asterias spp., which settle on kelp fronds, and $O$. aculeata, which shelters within the holdfasts. Kelp beds also harbour predators that consume juveniles of these and other species (such as $S$. droebachiensis) which are not found on the fronds or may be less cryptic in the early juvenile stages. Between-habitat differences in post-settlement mortality also may be related to differences in the assemblage of predators, which have different prey preferences or predation rates. Juvenile echinoderms are prey to various invertebrate and fish predators, but the role that predation plays in differential post-settlement survival remains unclear (reviewed by Scheibling 1996, Balch \& Scheibling in press).

Greater recruitment of most echinoderm species at Mill Cove than Little Duck Island was consistent with greater settlement at Mill Cove, but this also may be related to differences in availability of suitable refugia, or the types or abundance of predators at the 2 sites. For example, the boulders at Mill Cove provide undersides and crevices that may shelter juveniles from predation more effectively than the more open substratum at Little Duck Island. In caging experiments in a cobble bed in Nova Scotia, Scheibling \& Hamm (1991) recorded a lower rate of predation on juveniles of Strongylocentrotus droebachiensis which sheltered among cobbles and small boulders compared to those without a spatial refuge.

\section{Does settlement predict recruitment?}

Settlement of the dominant species of echinoderms at our sites does predict recruitment; however, the strength of the relationship varies, probably because of differing post-settlement processes. Strongylocentrotus droebachiensis showed a strong relationship whereby recruitment in all years, sites and habitats was proportionate to settlement measured in the same location $1 \mathrm{yr}$ earlier. This suggests that rates of settlement of this species could be used to predict recruitment of 1 yr olds, which may be beneficial for management of the local echinoid fishery (Hatcher \& Hatcher 1997). Fluctuating patterns of settlement of Asterias spp. among sites, habitats and years resulted in a weaker relationship, although recruitment was generally greater in kelp beds. The strength of the relationship between settlement and recruitment for Ophiopholis aculeata was similar to that for Asterias spp., but the slope of the regression line was much lower, indicating greater post-settlement mortality of these ophiuroids. There was no relationship between settlement and recruitment of Ophiura spp.: recruitment was minimal throughout the study, despite at least $1 \mathrm{yr}$ of high settlement, indicating high post-settlement mortality (possibly because of a lack of suitable sedimentary habitat at our rocky sites).

Our study demonstrates the importance of settlement and post-settlement processes in determining the population structure, distribution and abundance of mobile benthic marine invertebrates with dispersing larvae. For most of the echinoderm species we studied, recruitment did reflect settlement patterns, although the importance of post-settlement processes in determining recruitment varied among species, habitats and sites. Heavy settlement events occurred sporadically at our sites and in different years for different species. These events clearly were important determinants of subsequent recruitment, although the causes of such events and mechanisms regulating supply of larvae and survival of juveniles are not well understood. The temporal and spatial variability that we observed within and between species/genera underscores the need to monitor settlement and recruitment at varying scales of space and time to better understand their role in population dynamics.

Acknowledgements. This work would not have been possible without the assistance of numerous hands in both the field and laboratory whose help was greatly appreciated. We would especially like to thank M. Barbeau, T. Carlson, A. Carsen, G. Croft, I. Dempsey, T. Henderson, A. Hennigar, S. Kleinman, S. Lothian, D. Mackey, S. March, P. McKenna, S. Meidel, L. Scott, A. Shaw, P. Simard, S. Smith, L. Taylor, S. F. Watts, A. Windust and P. Winger. We are very grateful to L. 
Mosher for generously providing wharf and mooring facilities. Thanks also to J. Dearborne, R. Emlet, L. Harris, G. Hendler, D. McNaught, D. Medieros-Bergen and P. Tyler for assistance with species identification. Our research was funded by a Natural Science and Engineering Research Council Operating Grant to R.E.S. and a Dalhousie Graduate Fellowship and Patrick Lett Graduate Bursary to T.B.

\section{LITERATURE CITED}

Agassiz A, Faxon W, Mark EL (1883) Selections from embryological monographs: II. Echinodermata. Mem Mus Comp Zool 9:1-45

Balch T, Scheibling RE (in press) Larval supply, settlement and recruitment in echinoderms. In: Lawrence J, Jangoux M (eds) Echinoderm studies, Vol 6. AA Balkema, Rotterdam

Balch T, Scheibling RE, Harris LG, Chester CM, Robinson SMC (1998) Variation in settlement of Strongylocentrotus droebachiensis in the northwest Atlantic: effects of spatial scale and sampling method. In: Mooi R, Telford M (eds) Echinoderms: San Francisco. AA Balkema, Rotterdam, p 555-560

Balch T, Hatcher BG, Scheibling RE (1999) A major settlement event associated with minor meteorologic and oceanographic fluctuations. Can J Zool 77:1657-1662

Barker MF, Nichols D (1983) Reproduction, recruitment and juvenile ecology of the starfish, Asterias rubens and Marthasterias glacialis. J Mar Biol Assoc UK 63:745-765

Boolootian RA (1966) Reproductive physiology. In: Boolootian RA (ed) Physiology of Echinodermata. Interscience Publishers, New York, p 561-613

Booth DJ, Brosnan DM (1995) The role of recruitment dynamics in rocky shore and coral reef fish communities. In: Begon M, Fitter AH (eds) Advances in ecological research. Academic Press Ltd, London, p 309-385

Butman CA (1987) Larval settlement of soft-sediment invertebrates: the spatial scales of pattern explained by active habitat selection and the emerging role of hydrodynamical processes. Oceanogr Mar Biol Annu Rev 25:113-165

Caley MJ, Carr MH, Hixon MA, Hughes TP, Jones GP, Menge BA (1996) Recruitment and the local dynamics of open marine populations. Annu Rev Ecol Syst 27:477-500

Connell JH (1985) The consequences of variation in initial settlement vs. post-settlement mortality in rocky intertidal communities. J Exp Mar Biol Ecol 93:11-45

Dayton PK, Tegner MJ (1984) The importance of scale in community ecology: a kelp forest example with terrestrial analogs. In: Price PW, Slobodchitkoff CN, Gaud WS (eds) A new ecology - novel approaches to interactive systems. John Wiley \& Sons, New York, p 457-481

Dempsey IC (1996) Effects of disturbance on the recolonization rates of benthic macroalgae and invertebrates in a kelp bed and barren ground in Nova Scotia. Honours thesis, Dalhousie University, Halifax

Ebert TA (1983) Recruitment in echinoderms. In: Jangoux M, Lawrence J (eds) Echinoderm studies, Vol 1. AA Balkema, Rotterdam, p 169-203

Ebert TA, Russell MP (1988) Latitudinal variation in size structure of the west coast purple sea urchin: a correlation with headlands. Limnol Oceanogr 33:286-294

Ebert TA, Schroeter SC, Dixon JD, Kalvass P (1994) Settlement patterns of red and purple sea urchins (Strongylocentrotus franciscanus and S. purpuratus) in California, USA. Mar Ecol Prog Ser 111:41-52

Eckman JE, Duggins DO (1991) Life and death beneath macrophyte canopies: effects of understory kelps on growth rates and survival of marine, benthic suspension feeders. Oecologia 87:473-487

Eckman JE, Duggins DO, Sewell AT (1989) Ecology of understory kelp environments. I. Effects of kelps on flow and particle transport near the bottom. J Exp Mar Biol Ecol 129:173-187

Gerard VA, Mann KH (1979) Growth and production of Laminaria longicruris (Phaeophyta) populations exposed to different intensities of water movement. J Phycol 15:33-41

Gosselin LA, Qian PY (1997) Juvenile mortality in benthic marine invertebrates. Mar Ecol Prog Ser 146:265-282

Harris LG, Rice B, Nestler EC (1994) Settlement, early survival and growth in a southern Gulf of Maine population of Strongylocentrotus droebachiensis (Müller). In: David B, Guille A, Féral JP, Roux M (eds) Echinoderms through time. AA Balkema, Rotterdam, p 701-706

Harrold C, Pearse JS (1987) The ecological role of echinoderms in kelp forests. In: Jangoux M, Lawrence JM (eds) Echinoderm studies, Vol 2. AA Balkema, Rotterdam, p 137-233

Harrold C, Lisin S, Light KH, Tudor S (1991) Isolating settlement from recruitment of sea urchins. J Exp Mar Biol Ecol $147: 81-94$

Hart MW, Scheibling RE (1988) Heat waves, baby booms, and the destruction of kelp beds by sea urchins. Mar Biol 99: 167-176

Hatcher BG, Hatcher AI (1997) Research directions and management options for sea urchin culture in Nova Scotia. Bull Aquacult Assoc Can 97:62-65

Heath RA (1973) Flushing of coastal embayments by changes in atmospheric conditions. Limnol Oceanogr 18:849-862

Himmelman JH, Dutil C (1991) Distribution, population structure and feeding of subtidal seastars in the northern Gulf of St. Lawrence. Mar Ecol Prog Ser 76:61-72

Hunt HL, Scheibling RE (1997) Role of early post-settlement mortality in the recruitment of benthic marine invertebrates. Mar Ecol Prog Ser 155:269-301

Jackson GA, Winant CD (1983) Effect of a kelp forest on coastal currents. Cont Shelf Res 2:75-80

Johnson DR, Hester BS, McConaugha JR (1984) Studies of wind mechanism influencing the recruitment of blue crabs in the Middle Atlantic Bight. Cont Shelf Res 3:425-437

Keesing JK, Cartwright CM, Hall KC (1993) Measuring settlement intensity of echinoderms on coral reefs. Mar Biol 117:399-407

Leinaas HP, Christie H (1996) Effects of removing sea urchins (Strongylocentrotus droebachiensis): stability of the barren state and succession of kelp forest recovery in the east Atlantic. Oecologia 105:524-536

Loder JW, Han G, Hannah CG, Greenberg DA, Smith PC (1997) Hydrography and baroclinic circulation in the Scotian Shelf region: winter vs summer. Can J Fish Aquat Sci (Suppl) 54:40-56

Loosanoff VL (1964) Variations in time and intensity of settling of the starfish, Asterias forbesi, in Long Island Sound during a twenty-five-year period. Biol Bull 126:423-439

López S, Turon X, Montero E, Placín C, Duarte CM, Tarjuelo I (1998) Larval abundance, recruitment and early mortality in Paracentrotus lividus (Echinoidea). Interannual variability and plankton-benthos coupling. Mar Ecol Prog Ser 172:239-251

Medeiros-Bergen DE, Perna NT, Conroy JA, Kocher TD (1998) Identification of ophiuroid post-larvae using mitochondrial DNA. In: Mooi R, Telford M (eds) Echinoderms: San Francisco. AA Balkema, Rotterdam, p 399-404

Meidel SK, Scheibling RE (1998) Annual reproductive cycle of 
the green sea urchin, Strongylocentrotus droebachiensis, in differing habitats in Nova Scotia, Canada. Mar Biol 131: 461-478

Meidel SK, Scheibling RE, Metaxas A (1999) Relative importance of parental and larval nutrition on larval development and metamorphosis of the sea urchin, Strongylocentrotus droebachiensis. J Exp Mar Biol Ecol 240:161-178

Menge BA (1986) A preliminary study of the reproductive ecology of the sea stars Asterias vulgaris and A. forbesi in New England. Bull Mar Sci 39:467-476

Miller BA, Emlet RB (1997) Influence of nearshore hydrodynamics on larval abundance and settlement of sea urchins Strongylocentrotus franciscanus and $S$. purpuratus in the Oregon upwelling zone. Mar Ecol Prog Ser 148:83-94

Miller RJ (1985) Succession in sea urchin and seaweed abundance in Nova Scotia, Canada. Mar Biol 84:275-286

Minchinton TE, Scheibling RE (1993) Variations in sampling procedure and frequency affect estimates of recruitment of barnacles. Mar Ecol Prog Ser 99:83-88

Nichols D, Barker MF (1984) Growth of juvenile Asterias rubens L. (Echinodermata: Asteroidea) on an intertidal reef in southwestern Britain. J Exp Mar Biol Ecol 78: 157-165

Ólafsson EB, Peterson CH, Ambrose WG (1994) Does recruitment limitation structure populations and communities of macro-invertebrates in marine soft sediments: the relative significance of pre- and post-settlement processes. Oceanogr Mar Biol Annu Rev 32:65-109

Olsen H (1943) The development of the brittle-star Ophiopholis aculeata (O. Fr. Müller), with a short report on the outer hyaline layer. In: Gaarder T, Nordhagen R, Shetelig H (eds) (Årbok Univ Bergen [Mat-naturvitensk ser]). AS John Griegs Boktrykkeri, Bergen, p 4-107

Packer DB, Watling L, Langton RW (1994) The population of the brittle star Ophiura sarsi Lutken in the Gulf of Maine and its trophic relationship to American plaice (Hippoglossoides platessoides Fabricius). J Exp Mar Biol Ecol 179:207-222

Pearce CM, Scheibling RE (1990) Induction of metamorphosis of larvae of the green sea urchin, Strongylocentrotus droebachiensis, by coralline red algae. Biol Bull 179:304-311

Pearce CM, Scheibling RE (1991) Effect of macroalgae, microbial films, and conspecifics on the induction of metamorphosis of the green sea urchin Strongylocentrotus droebachiensis (Müller). J Exp Mar Biol Ecol 147:147-162

Pearse V, Pearse J, Buchsbaum M, Buchsbaum R (1987) Living invertebrates. Blackwell Scientific Publications/The Boxwood Press, Paulo Alto/Pacific Grove

Pedrotti ML, Fenaux L (1992) Dispersal of echinoderm larvae in a geographical area marked by upwelling (Ligurian Sea, NW Mediterranean). Mar Ecol Prog Ser 86:217-227 Petrie B, Topliss BJ, Wright DG (1987) Coastal upwelling and

Editorial responsibility: Roger Hughes (Contributing Editor), Bangor, Wales, UK eddy development off Nova Scotia. J Geophys Res 29: 12979-12991

Raymond BG, Scheibling RE (1987) Recruitment and growth of the sea urchin Strongylocentrotus droebachiensis (Müller) following mass mortalities off Nova Scotia, Canada. J Exp Mar Biol Ecol 108:31-54

Rumrill SS (1988) Larval populations of Strongylocentrotus droebachiensis in Barkley Sound, British Columbia. In: Burke RD, Mladenov PV, Lambert P, Parsley RL (eds) Echinoderm biology. AA Balkema, Rotterdam, p 811

Russell-Hunter WD (1979) A life of invertebrates. Macmillan Publishing Co, Inc, New York

Scheibling RE (1986) Increased macroalgal abundance following mass mortalities of sea urchins (Strongylocentrotus droebachiensis) along the Atlantic coast of Nova Scotia. Oecologia 68:186-198

Scheibling RE (1996) The role of predation in regulating sea urchin populations in eastern Canada. Oceanol Acta 19: $421-430$

Scheibling RE, Hamm J (1991) Interactions between sea urchins (Strongylocentrotus droebachiensis) and their predators in field and laboratory experiments. Mar Biol 110:105-116

Scheibling RE, Hennigar AW, Balch T (1999) Destructive grazing, epiphytism, and disease: the dynamics of sea urchin-kelp interactions in Nova Scotia. Can J Fish Aquat Sci 56:2300-2314

Smith GFM (1940) Factors limiting distribution and size of starfish. J Fish Res Board Can 5:84-103

Strathmann MF (1987) Reproduction and development of marine invertebrates of the northern Pacific coast. University of Washington Press, Seattle, WA

Strathmann RR (1978) Length of pelagic period in echinoderms with feeding larvae from the northwest Pacific. J Exp Mar Biol Ecol 34:23-27

Tegner MJ, Dayton PK (1981) Population structure, recruitment and mortality of two sea urchins (Strongylocentrotus franciscanus and S. purpuratus) in a kelp forest. Mar Ecol Prog Ser 5:255-268

Todd CD, Laverack MS (1991) Coastal marine zooplankton: a practical manual for students. Cambridge University Press, Cambridge

Underwood AJ, Fairweather PG (1989) Supply-side ecology and benthic marine assemblages. Trends Ecol Evol 4: $16-20$

Wing SR, Botsford LW, Largier JL, Morgan LE (1995a) Spatial structure of relaxation events and crab settlement in the northern California upwelling system. Mar Ecol Prog Ser 128:199-211

Wing SR, Largier JL, Botsford LW, Quinn JF (1995b) Settlement and transport of benthic invertebrates in an intermittent upwelling region. Limnol Oceanogr 40:316-329

Submitted: November 17, 1999; Accepted: April 26, 2000 Proofs received from author(s): September 25, 2000 